\title{
Fra randen
}

\section{Om orden og orienteringsløshed i Herman Melvilles roman Moby-Dick}

Et år før udgivelsen af Moby-Dick skriver Herman Melville til en ven om sit arbejde med det mægtige romankorpus:

„Det bliver en mærkelig bog, er jeg bange for; hvalspæk er hvalspæk, ved du nok; skønt man kan få olie ud af det, løber poesien som saften fra et frossent ahorntræ: og for at brygge den sammen må man bruge en smule vid, som i sagens natur må være lige så uskøn som hvalernes egne hop. Dog mener jeg at give sandheden om sagen på trods af dette. ${ }^{1}$

Bogen tegner til at blive mærkelig, for den vil ikke ordne sig i en poetisk helhed. Lige så lidt som saften strømmer fra et frossent ahorntræ, løber poesien forfatteren i pennen. Med andre ord er verden i Herman Melvilles roman, Moby-Dick, fra 1851 blevet prosaisk. Tingenes indre mening er svundet ind og har nivelleret genstandene til blot og bar masse - »spæk«. Betydningen vokser ikke organisk ud af tingene, men må fravristes materialiteten gennem slidsomt arbejde.

Det gælder ikke kun for fiktionen. Omkring midten af det 19. århundrede har prosaen gjort sit indtog i den amerikanske virkelighed. Tingenes orden begynder at ligge fast. Tidligere har det amerikanske rum været grundlæggende åbent, men nu er mulighederne snævret ind af en gennemgribende kodificering af rummet. Det uberørte land, som før strakte sig uendeligt for fødderne af det frie subjekt, er i 1850'ernes antebellum-Amerika knap så uberørt. Urbaniseringen er i rivende udvikling, og de sociale diskurser har efterhånden sedimenteret sig i byerne. Individet er nu bundet af retlige og normative forpligtelser, som fratager det evnen til at handle på egne vegne. Hver gang subjektet forsøger at realisere sin individualitet ved at

1. Brev fra Herman Melville til Richard H. Dana. 1. maj, 1850. Optrykt i Herman Melville: Moby-Dick, New York 1967, p. 552. 
sætte sin egen virkelighed fra grunden, støder det ind i den fastlagte sociale orden. Ordenens uomgængelighed tvinger den enkelte til at kanalisere sine ønsker og mål ud inden for rammerne af en række på forhånd givne diskurser af økonomisk, politisk og videnskabelig beskaffenhed.

Subjektets autonome frihed er altså blevet indskrænket af en spatial magtstruktur. Rummet er ikke længere bare rum, men et differentieret felt af diskurser, der hævder deres suverænitet i forhold til subjektet. De områder, hvor individet enerådigt kan realisere sin subjektive sandhed, er således blevet få. Kun på randen af den hastigt voksende orden er dette endnu muligt - som for eksempel på verdenshavene.

For Ishmael, Moby-Dicks pseudonyme jeg-fortæller, er byernes trange virkelighed begrundelsen for at stå til søs. ${ }^{2}$ Uden hverken ejendom eller et navn, der binder ham til socialiteten, drager Ishmael til det gudsforladte New Bedford for at tage hyre som hvalfanger. Sammen med kannibalen, Queequeg, finder han arbejde på skibet »The Pequod«. Rejsen bliver for Ishmael en mulighed for at genopdage den indre såvel som ydre verdens mangfoldighed. Den eneste begrænsning for hans udfoldelse er skibets fører, kaptajn Ahab, som for år tilbage har mistet et ben i kamp med en hval, der er kendetegnet ved en rædselsvækkende hvidhed. Mødet med den hvide hval har ikke blot mærket Ahabs krop, men også drevet enhver forestilling om meningsmæssig sammenhæng ud af kaptajnen. Han er blevet besat af tanken om hævn over dyret. Men Ahab når aldrig sit mål. I stedet driver hans monomane fiksering skibets besætning i døden. Den eneste overlevende er Ishmael, der kan vende tilbage til fastlandet og fortælle sin historie.

Sådan er den ekstremt forsimplede struktur i Melvilles kompakte roman på knap seks hundrede sider. Resten er betydning eller mangel på samme. Havets enorme vidder er i Moby-Dick et rum, hvor betydningen stadig er åben. Radikalt åben. I takt med at de meningsfulde områder i verden bliver formindsket, vokser omfanget af det tomme rum tilsvarende. Den prosaiske virkelighed gør på én gang verden mindre og større. Rummets ubegrænsethed giver en frihed, der medfører, at betydningen formelig eksploderer. For hvor der ingen betydning er, kan betydningen frit sættes. Havet er i romanen et laboratorium for, hvordan betydning dannes og ikke mindst for den baggrund, hvorpå den dannes. Det får karakter af en omfattende tabula

2. Jeg anvender i det følgende Moby-Dick eller Hvalen, oversat til dansk af Mogens Boisen, Kbh. 2001 og Moby-Dick, Norton Critical Edition, New York 1967. Der citeres i teksten fra begge udgaver, forkortet $M D$. Første sidetalsangivelse henviser til den danske oversættelse. På et enkelt punkt har jeg modificeret Boisens oversættelse, idet jeg bibeholder de engelske egennavne frem for hans danske oversættelse af dem. Alle øvrige oversættelser er mine egne. 
rasa, der gør tingene læsbare på ny. Efterhånden som skibet »The Peqoud« bevæger sig længere bort fra civilisationen, løsnes de forskellige diskurser fra deres tilsyneladende faste grund og bliver dermed gjort synlige. Det gælder de enkelte diskursers immanente strukturering, men i endnu højere grad det grundlag, som funderer dem.

I Moby-Dick viser den diskursive orden sig at være baseret på et sæt af mytiske antagelser, der har deres oprindelse i en fortid, som ikke længere er adækvat i forhold til den historiske virkelighed. De mytiske antagelser er netop mytiske, fordi de ikke lader sig verificere i den forhåndenværende realitet. Myten modsætter sig altid integration i en given virkelighed. Dens grundlæggende historier er sjældent lokaliseret i et defineret rum og kan aldrig identificeres i en bestemt tid. Men omvendt skyer myten også det tomme rum på samme vis, som det senere, mytisk, er blevet sagt om naturen. Mytens eneste fasthed består i dens indlejring i en genealogisk struktur. ${ }^{3}$ I kraft af slægtens ubrudte kontinuum mellem en mytisk oprindelse og en lige så mytisk fremtid, har den nutidige orden fast grund under fødderne. Med genealogien giver myten et statisk billede af tiden. For tingenes orden er af samme kød og blod som den oprindelige struktur, der på tværs af historien er gået i arv fra fader til søn. Ingen levende person har sat ordenens transhistoriske gyldighed, men blot givet den liv og legemligt nærvær i sit eget afkom.

Hos Melville mister myten sin eneste mulighed for integration og bliver hjemløs. I oceanernes tomme rum finder den intet forankringspunkt. Havets blanke overflade kaster myten tilbage på sig selv og reflekterer dens forsøg på at fæstne sig som imaginære projektioner. Ligeledes yder skibets isolerede fællesskab af udstødte sømænd modstand mod mytens integration. Mandskabets ensidige kønsfordeling kan selvsagt ikke være afsæt for en orden, der er genealogisk betinget. En verden af mænd giver intet løfte om kommende generationers fornyende liv og fratager myten et perspektiv i fremtiden. I Moby-Dick fortaber myten sig derfor i et løsrevet billede af sig selv. Og som sit eget barn, Narcissus, går den under. ${ }^{4}$

3. Hans Blumenberg: Arbeit am Mythos, Frankfurt a.M 1996, p. 46.

4. Narcissus-figuren optræder i romanens indledende kapitel: "Hvorfor anså de gamle persere havet for helligt? Hvorfor gav grækerne det en særskilt guddom, en broder til selve Zeus? Alt dette er visselig ikke uden dybere betydning. Og endnu dybere er betydningen af hin historie om Narcissus, der kastede sig i vandet og druknede, fordi han ikke kunne fange det pinagtige, milde spejlbillede, han så i kilden. Men det selvsamme spejlbillede ser vi selv i alle floder og have." $M D$, p. $27 / 14$. 
Hermed åbner en afgrund sig mellem nutid og fortid. Den sociale orden, der er kendetegnet ved en ubrudt kontinuitet mellem fortid, nutid og fremtid, mister sin legitimitet. Tabet af fortiden udmønter sig i, at verden fremtræder som tømt for betydning, og en voksende tidslig orienteringsløshed erstatter mytens stillestående billede af historien. Uden et fastlagt skema at ordne realiteten under, er sansningens vekslende udgaver af virkeligheden et faktum, man må tage stilling til. Tegnene har ikke en bestemt betydning, men allehånde betydninger. Således mister virkeligheden på den ene side betydningsfylde, mens den på den anden side vinder sin sanselige fylde massivt tilbage.

Da kontinuiteten mellem fortid, nutid og fremtid endnu herskede, havde fortiden karakter af at være et levende meningsunivers, man kunne handle og bevæge sig i forhold til. Nu viser den sig som fundamentalt fraværende, død. Fortidens fravær tømmer de historiske tegn for betydning og forvandler dem til leksikalske brokker. Tegnene allegoriseres og åbner historien for alle mulige læsninger. I stedet for at være en snæver ramme for meningen bliver historien et uendeligt virtuelt rum for betydningssættelse. Erfaringen af et meningstab bliver oplevet som uindskrænket frihed, hvor historie og myte kan læses efter forgodtbefindende.

Dialektikken mellem tomhed og fylde gør Melvilles Moby-Dick til et tvedelt univers, som hele tiden pendulerer mellem et meningsmæssigt for lidt og for meget. Enten er intet læseligt eller også er alt læseligt. Som læser af romanen har man en oplevelse af at fortabe sig i det uendelige fond af betydninger, idet man simpelthen er ude af stand til at tage romanens myriader af tegn ind i en samlende bevægelse. Omvendt fornemmer man samtidig, at der bag forvirringen blot gemmer sig en tom flade, man selv har været med til at fylde.

I det følgende læser jeg på det radikale kritiske potentiale som dette ustabile romanunivers giver i forhold til amerikansk kultur og selvforståelse anno 1850. Fokus vil ligge på romanens kritik af samtidens mytiske, religiøse og retoriske bestræbelser på med vold og magt at genoprette en stabil orden. Som modvægt hertil optræder kroppen som en sidste pragmatisk mulighed, der undslipper de diskursive bemestringer.

\section{Typen}

I det fletværk af mytiske konstruktioner, Moby-Dick stiller til skue, er den amerikanske typologi den mest centrale. Typologien rækker tilbage til amerikansk kulturs oprindelse. Da puritanerne ankom til New England 
vakte den ny verdens overvældende natur angst, men rummede også løftet om en ny og bedre civilisation. Man mente, at det jomfruelige land havde en regenererende effekt på den medbragte europæiske civilisation, som i vid udstrækning blev anset for korrumperet. Puritanerne baserede derfor deres imperiale projekt på overbevisningen om, at en isoleret, sand kerne af europæisk religion og civilisation med dem var blevet overført til 'The New World'. I udgangspunktet var denne sandhed en latinsk imperietanke, men blev efterhånden erstattet af idéer fra den hebræiske sfære. I bibelen fandt man både et paradisisk forlæg for den amerikanske natur og løftet om gudsrigets komme. Det hebræiske idégods leverede således en virkelighedsforståelse, der sikrede overgangen mellem en ubesmittet begyndelse og en strålende fremtid. Det udmøntede sig konkret i typologien, der er en profetisk model for historien. Ordet »typos« er græsk og betyder »et slag« eller »det som opstår ved et slag«, »indtryk«, "spor«, "mærke«, »indprentning«, »skulptur", "form«, "figur« »billede« ${ }^{5}$ Tingene bærer mærker af en mening, der er præget i dem fra den hebræiske oprindelse. Ved at tyde de indprentede tegn fra skaberens oprindelige akt, bliver denne mening atter nærværende. Med andre ord er naturen guds bog. Derfor er de samme guddommelige spor at finde i begivenheder og personer. I typologien præfigurerer en fortidig figur en efterfølgende person, som så inkorporerer og opfylder den betydning, der oprindeligt var nedlagt i typens faste præg. Den stemmer i overordnede træk overens med den form for profetisk historiekonstruktion, Erich Auerbach betegner som figural. ${ }^{6}$ Som figuraen er den fortidige prototype og nutidige type virkelige personer, der er adskilte i tid. Læsningen af typen er grundlæggende allegorisk, men afviger som den figurale læsning fra de fleste allegorier ved, at både tegnet og referenten er historiske. ${ }^{7}$ I modsætning til en moderne horisontal opfattelse af historien som succession indebærer figuraen altid et vertikalt hierarki. Historiens begivenheder fortolkes ovenfra og adskilt fra hinanden i relation til den endelige åbenbaring af gudsriget, hvilket gør dem foreløbige og ufuldstændige. ${ }^{8}$

Den typologiske historiekonstruktion aktualiserer fortidens religiøse betydningsindhold, så det fremstår med et præsentisk nærvær i bevidstheden. ${ }^{9}$ Eftersom relationen mellem prototype og type i bund og grund er allegorisk, sker dette i kraft af en retorisk personifikation, der tilskriver det

5. Ursula Brumm: American Thought and Religious Typology, New Jersey 1970, p. 21.

6. Det græske ord 'typos' blev oversat til latin som 'figura'. Erich Auerbach: „Figura», in Scenes from the Drama of European Literature, New York 1959, p. 14.

7. Op. cit., p. 53.

8. Op. cit., p. 50.

9. Op. cit., p. 50. 
fraværende liv og karakter..$^{10}$ Den retoriske figur for personifikation er prosopopoeia og betyder på græsk 'at give ansigt til'. Personifikationen giver således fortidens prototype et konkret 'ansigt' i typens krop. Idet typen inkorporerer prototypen, er han den levende enhed af nutid og fortid og ophæver dermed den egentlige afstand mellem tegn og referent.

Typologien er en imaginær konstruktion, der skal beskytte individet mod en angstvækkende virkelighed. Ved personificerende at benævne realiteten som noget allerede kendt domesticeres problemer i den historiske nutid. Navngivningens antropomorficerende akt er ifølge Hans Blumenberg den fælles arkaiske grund for både myte og videnskab:

"Enhver fortrolighed med verden begynder med navnene, til hvilke man kan fortælle historier. Denne kendsgerning gemmer sig i bibelens tidligste historie om den paradisiske navngivning. Men den gemmer sig også i den tro, som ligger i al magi, på samme måde som den bestemmer videnskabens begyndelser, at den træffende benævnelse ophæver fjendskabet mellem dem [tingene] og mennesket til ren tjenstvillighed. Den rædsel som har fundet tilbage til sproget, er allerede overstået. «11

Den typologiske læsning af naturen som et - selv oprindeligt - udtryk for en oprindelig tilstand, paradiset, rummer således både et besværgende moment, og en instrumentel, videnskabelig model til at tilegne sig naturen i sit eget billede. Myte og videnskab bunder i en fælles antropologisk interesse, nemlig at blive herrer over tingenes skræmmende kaos.

Da Herman Melville skriver Moby-Dick, har typologien mistet sin betydning på overfladen af det amerikanske samfund. Indtil omkring år 1800 konsulterede man typologien i samfundsdebatten, når man skulle afgøre nationale anliggender, men i årene op til den amerikanske borgerkrig er den stort set borte. Typologiens forsvinden skyldes, at modellens simple struktur ikke var en overbevisende løsning på samtidens komplekse interne problemer. Som middel til at sikre den nationale enighed trådte i stedet andre diskurser, som for eksempel Ralph Waldo Emersons begreb om »self-reliance«.

At typologien forsvandt fra den offentlige scene, betød imidlertid ikke, at den ophørte med at være virksom under diskursernes retoriske fernis. I Moby-Dick fremstiller Melville typologien som et arkaisk paradigme, der ligger til grund for en lang række tilsyneladende moderne og sekulære diskurser. Det gælder romanens naturvidenskabelige forsøg på at omsætte

10. Heinrich Lausberg: Elemente der Literarischen Rhetorik, München 1963, § 2.936 og $§ 425$.

11. Blumenberg p. 41 . 
hvalen i en stabil taksonomi, Ahabs forestilling om at være et selvberoende individ, samt den økonomiske udbytning af naturen. Diskursernes bestræbelse på at naturalisere den givne ordens mytiske fundament i en sekulær retorik trænger op til overfladen. Hermed afslører Melville, at det, der tilsyneladende drejede sig om sandhed, i virkeligheden er et spørgsmål om overbevisning.

\section{Det sublime}

I Moby-Dick spiller det sublime en markant rolle. Melville var bekendt med Edmund Burkes sensualistiske udgave af det sublime i A Philosophical Enquiry. I romanen optræder utallige beskrivelser, der bygger på eksempler fra Burkes bog, såsom hvidheden, havets uendelige flade og mørkets magt. I det hele taget ligger de uklare beskrivelser af hvalens skrækindjagende magt i forlængelse af Burke, der afviser, at det sublime lader sig imitere i en klar, billedlig fremstilling. ${ }^{12}$ Min læsning af det sublime i Moby-Dick vil dog koncentrere sig om Hegels definition af begrebet, der knytter an til både typologien og det prosaiske.

Ifølge Hegel træder prosaen ind i verden, da den oprindelige enhed mellem ord og ting, mening og væren bliver splittet. Oprindeligt realiserede meningens totalitet sig umiddelbart i den poetiske tale. Uden forskel mellem ord og genstand var den blotte udsigelse identisk med meningstotalitetens nærvær. Loven var ikke splittet fra fremtrædelsen, og målet endnu ikke fra midlet. ${ }^{13}$ Det sker med den sublime kunst. Hos Hegel betegner det sublime bestræbelsen på at udtrykke en uendelig meningstotalitet, som ikke lader sig fremstille i den endelige genstandsverden. Derfor forbliver den uudtalelig og hævet over ethvert endeligt udtryk. Hegel finder det sublime repræsenteret i den hebræiske verdensanskuelse og poesi. I den mosaiske litteratur reflekterer tingenes endelighed guds uendelige og magtfulde enhed. ${ }^{14}$ Herren har trukket sig tilbage fra den sanselige virkelighed og figurerer som en selvstændig meningstotalitet. Gud er én og overalt, men hans altfavnende enhed overskrider det ydre i absolut forstand, således at kun forskellen mellem endeligheden og en uendelig indre mening kommer til udtryk. Ver-

12. Burke, Edmund: A Philosophical Enquiry into the Origins of our Ideas of the Sublime and Beautiful. Oxford 1990, p. 55.

13. G.W.F Hegel: Vorlesungen über die Ästhetik III, Werke, Bd.15, Frankfurt a. M 1986, p. 240.

14. Den panteistiske (Hegels ord) mening kan aldrig repræsenteres i et endeligt billede, men netop kun forestilles i litteraturens indirekte fremstilling. 
dens immanente fylde er slået om i negativitet - magtesløs kreaturlighed. Ifølge Hegel er skabelsen, som den fremstilles i Genesis, derfor det reneste udtryk for det sublime: »Og gud sagde: »Der blive lys!» Og der blev lys». Hegel låner sit eksempel fra Longinus og kalder det »Et slående [schlagendes] eksempel på det sublime«. Godt nok udtrykker herren noget i disse ord, men det er »den reneste, selv ulegemlige, æteriske ytring: Ordet, ytringen af tanken som dens ideale magt, med hvis befaling om væren det værende nu også umiddelbart er sat i stum lydighed. $\aleph^{15}$ De slående ord sætter med ét den absolutte forskel mellem guds lov og den endelige verdens magtesløse tilfældigheder. ${ }^{16}$ Forestillingen om, at tingenes naturlige orden avles organisk af gud, viger for en voldelig skabelse gennem åndelig magt. Verdens prosa er sat: „For første gang træder naturen og menneskeskikkelsen nu frem for os prosaisk og uden sine guder. $\aleph^{17}$

Prosaen fikserer tingene i en forståelig bestemthed, som gør dem hjemlige. I modsætning til den ufærdige verdens virvar finder mennesket nu plads i tingenes orden, der med ét præges som naturlig patriarkalsk:

"[V]i har figurer for os, som fremtræder ganske naturligt og hvis faste patriarkalske karakterer står os fuldstændigt forståeligt nær i deres bestemthed og sandhed. $\|^{18}$

Mennesket er hjemme i verden, fordi det underlægger sig en faderlov, der er indprentet i figurernes faste karakter og fikserede sandhed. Hegel understreger endnu en gang denne "slående sættelse«, da han vender tilbage til den sublime skabelse i sit afsnit om poesi og prosa:

"[D]er findes vel et rent indhold, som danner et i sig lukket hele, [og] dog allerede er fuldendt i en sætning uden videre udvikling og bevægelse. Om et sådant indhold kan man egentlig ikke sige, om det skal henregnes til poesi eller prosa. Det gamle testamentes store ord for eksempel: „Gud sagde, der blive lys, og der blev lys", er i sin renhed og slående affattelse [Gediegenheit und schlagende Fassung] for sig den højeste poesi såvel som prosa. ${ }^{19}$

15. Hegel: Vorlesungen über die Ästhetik I, p. 481.

16. Ibid.

17. Op. cit. p. 482.

18. Ibid.

19. Hegel: Vorlesungen über die Ästhetik III, p. 250. 
Verdens kaos bliver altså bogstaveligt talt "fatteligt" i kraft af dets bestemthed i forhold til en statisk meningstotalitet. Med den sublime kunst identificerer Hegel et radikalt åndshistorisk moment, hvor meningen splittes fra verden. Men splittelsen er samtidig en soning i kraft af loven. Anerkender man begivenheden og underlægger sig loven, er man hjemme i verden.

\section{Faderen}

I det vigtige kapitel "Kapellet«, som falder i begyndelsen af Moby-Dick, knytter Herman Melville den sublime retorik sammen med amerikansk typologi. Ishmael er gået indenfor i New Bedfords kapel, hvor en lille menighed sidder indkapslet i deres private sorg og stirrer ensomt på mindetavler over tabte sømænd. Mindetavlerne er kenotaffer, tomme grave:

»Hvilke nagende tomrum i hine sortrandede marmortavler, der ikke skjuler jordiske levninger! Hvilken fortvivlelse i disse stive indskrifter! Hvilken dødelig tomhed og ubuden vantro i de linier, der synes at udfordre al tro og at nægte opstandelse til de væsener, der stedløst er omkommet uden grav. Disse tavler kunne lige så vel være opsat i Elephantas hule som her.«(MD, p. 60/41).

Ishmael ser, at tavlernes allegoriske løsrivelse fra kapellets forfrosne genius loci truer med at invertere deres funktion som anledning til kristen kontemplation og bøn til et kætteri.

Præsten fader Mapple beordrer »de spredt siddende tilhørere [at] rykke sammen [the scattered people to condense] ( $M D$ p. 64/44). Hvor tilhørerne hidtil har måttet nøjes med inskriptionerne, er føden nu den inkarnerede ånd - ordets kød og blod. Det levende ord skal sone tegnets spaltning og dermed modsætte sig allegoriens stase i en præsentisk strøm, der til stadighed formår at betyde. ${ }^{20}$ Mapple indleder gudstjenesten med oplæsningen af en bøn, der med maritim dramatik gør indholdet levende for menigheden. Herpå følger en hymne, sunget med brølende lyksalighed, hvilket samler menigheden i fælles lydhørhed mod prædikenen, der moduleres over bibelens fortælling om Jonas og hvalen. Fader Mapple oversætter det gammelte-

20. Det metaforiske sakramente, som forløber i Mapples tale skal altså ikke blot erindre om ordet, der blev kød, men vedvarende forny den oprindelige konvertering af mening til væren i overensstemmelse med verset i Johannes-evangeliet: „Og Ordet blev kød og tog bolig iblandt os«. »Johannes-evangeliet«: 1, 14. 
stamentlige univers til nutidens geografi, og genfinder mosaiske love og regler som kernen i det altomfattende økonomiske kredsløb i Amerika anno 1850.

Mapples prædiken har billedlig snarere end narrativ karakter, idet han begynder med slutningen og indledningsvis giver et resumé af den tekst, han skal foredrage. Også i omgivelserne er der tale om billedlighed. Bag fader Mapple hænger et maleri, der viser et sublimt øjeblik, hvor en lysende engel kigger ned gennem skyerne:

"[E]t stort maleri, som forestillede et stolt skib i kamp mod en frygtelig pålandsstorm nær en kyst med sorte klipper og skumhvid brænding. Men højt over det flyvende sprøjt og de tungt fremvæltende skyer svævede der en lille solskinsplet, fra hvilken et engleansigt strålede, og dette lyse ansigt kastede en klart afgrænset plet af stråleglans på skibets overskyllede dæk, omtrent som den sølvplade, der nu er indsat i den planke på 》Victory« hvor Nelson faldt«(MD, p. 63/43) .

Samme lysende ansigt finder vi i hymnen, som beskriver Jonas' tilbagevenden til gud, efter han har været i hvalens bug:

»I hast til hjælp mig HERREN kom/som båret af et marsvins krop [a radiant dolphin]/ Hans åsyn var nok strengt, men skønt; som gylden lynild steg Han op [Awful, yet bright, as lightening shone/The face of my Deliverer God]«(MD, p. 65/44).

Som sidste lag i stratificeringen af billede og hymne bryder lyset også pludselig frem i fader Mapples blik:

»Mens præsten sagde disse ord, syntes den tudende og piskende vinds hylen derude at give yderligere kræfter til ham, der ved beskrivelsen af Jonas' storm på havet selv forekom at være omtumlet af en storm. Hans bryst bølgede som i svær dønning, hans gestikulerende arme syntes at være selve de kæmpende elementer, og tordenen, der rullede bort fra hans sorte bryn, og lynet, som sprang fra hans øje, fik alle hans enfoldige tilhørere til at betragte ham med en levende frygt der var dem uvant [a quick fear that was strange to them ]« $(M D$, p. 71/49)

Præstens ansigt er fuldstændig læseligt og giver kødelig væren til prædikenens betydning, som »den levende guds lods«( $M D$, p.72/50). I et intenst øjeblik inkorporerer han figuralt fortiden med dramatisk aktualitet. Men, som 
det burde fremgå af læsningen ovenfor, afhænger typens øjeblikkelige og personificerede nærvær i Mapples krop i virkeligheden af en lagdeling af ord, billede og krop, der udspiller sig i tid. Ansigtet er indskrevet i en regressiv række af mimetiske gentagelser, af re-præsentationer, hvis bagudrettede struktur reelt ikke formår at fange andet end forskydningen af den identitet, den skulle inkarnere. Det underminerer Mapples autoritet, for faderloven kan som sådan ikke forklare sig, men kun henvise til tidsligt forudgående repræsentationer af loven. Således virker fader Mapples personificering af fortiden kun i kraft af en latent voldelig og sublim retorisk strategi.

I Ishmaels beskrivelse af gudstjenesten bliver den fortidige types voksende nærhed fulgt af en øget afstand til menigheden. Afstanden mellem taler og modtager giver rum for sættelsen af den patriarkalske lov. Fader Mapples ansigt virker som en mimisk Verfremdungseffekt, der chokerer tilhørerne: «a quick fear that was strange to them«. Hos Longinus betegner det sublime talerens evne til at overrumple sit publikum: „Bryder det ophøjede frem i det rette øjeblik, sprænger det alting som et lyn«. ${ }^{21}$ Talerens sublime 'lyn' gør tilhøreren ude af sig selv og åbner plads for en overbevisende retorik. Hermed markerer momentet præcis overgangen fra en sandhedsdiskurs til den rene overbevisning. Ved hjælp af sit sublime blik, der slår ned på menigheden, gestalter Mapple deres ikke-identitet med sig selv, hvilket er forudsætningen for faderlovens magt. I stedet for at skabe en samlende identitet mellem prædikant, menighed og mening, ender præstens indledende ordre til folket om at samle sig i en splittelse mellem et ord, der bliver stadig luftigere, og en tilhørerskare af simple folk, som bliver stadig mere kreaturlige. I forskellen retableres Mapples lovgivende autonomi, mens menighedens individualitet opløser sig i folkemassens identitetsløshed. Men den lære, Mapple eksplicit drager af sin prædiken, er den stik modsatte, nemlig at individets absolutte autonomi er den højeste dyd.

"Fryd er den vis, fryd højt oppe og indadtil, der stik imod denne verdens stolte afguder og kaptajner stedse forbliver sit eget jeg, forbliver det ubønhørligt [...] Lykkelig, ja salig er han, der ikke anerkender nogen lov eller herre uden Herren, hans Gud, og som ikke kender andet fædreland end himlen«. $(M D$, p. $73 / 51)$

Father Mapple skaber reelt en instrumentaliseret personlighedsmodel, hvor subjektet sættes fri til voldeligt at underlægge sig sine omgivelser qua dets absolutte forankring i loven. Uden at få anfægtet sit 'individuelle' jeg kan

21. Pseudo-Longin: Vom Erhabenen, red. Reinhard Brandt, Darmstadt 1966, p. 16. 
den enkelte nu forskyde den vold, han selv var offer for i prædikenen til havets dyr i hvalfangsten, som vi senere skal det hos Ahab. Men det ubønhørlige jeg, som Mapple voldeligt har konstitueret, hævder sin egen autonomi i kraft af en egentlig fremmedbestemthed, idet jeg'et bygger på en gentagelseslogik, som kun en udefra sat lov kan sanktionere. Jegets autonomi er altså i dobbelt forstand tvangsmæssig, for så vidt som den både er sat gennem tvang og udfolder sig som tvang.

\section{Fortælling}

Ishmaels jeg-fortælling er kendetegnet ved en gennemgribende modstand mod naturvidenskabelig, religiøs og æstetisk typologisering. Gang på gang afviser han at kunne ordne tingene i et systematisk skema, og ethvert forsøg på at diskursivere hvalen i en frenologisk, fysiognomisk og anatomisk type er dømt til at mislykkes. Det knytter an til fortællerrollen i Moby-Dick. Den centrale fortællesynsvinkel, der ville kunne underordne iagttagelserne en primær meningshorisont, bryder sammen i romanen og erstattes af en radikal perspektivisme. Hvor den typologiske model ser tingene gennem en uendelig fjern mening og dermed netop overser tingenes konkrete væren, er genstandsverdenen så at sige for tæt på hos Ishmael. Verden opleves fra en position nede mellem tingene. I kapitlet "Spermacethvalens hoved - sammenlignende betragtninger« bliver multiperspektivet eksemplificeret med den særegne placering af kaskelothvalens øjne. Dyrets bittesmå øjne befinder sig nemlig på hver sin side af hovedets enorme kødmasse. Det gør det umuligt for hvalen at opnå et centralt perspektiv på verden. I stedet oplever dyret flere virkelighedsversioner på en gang, hvilket gør det fremmed for en human blikvinkels kontrollerende verdensbillede. Med kroppens massive immanens fremstår dyret som et absolut Andet, mennesket aldrig vil kunne tilegne sig uden først at destruere det. Ishmaels narrative strategi synes at mime hvalens blik. Han undlader netop at destruere det værende under en voldelig synsvinkel som Mapple og senere Ahab. Hans fortælling glider konstant bort fra sin egentlige genstand, og Ishmael forfalder til at stifte analogier til en abstrakt betydning, der bliver repræsenteret ved en konkret historisk eller mytologisk figur eller genstand. Udgangspunktet er altid den sanselige verdens rigdom af detaljer. Herved fremskriver Ishmael ekstensive analogiske netværk mellem fortællingens intratekstuelle- såvel som intertekstuelle referencepunkter. Romanens plotmæssige kausalitet falder her bort til fordel for et væld af ikke-kausale forbindelser. ${ }^{22}$ Hos Ishmael føjer analogierne mellem genstand og teoretisk 
betydning sig dog aldrig sammen i en stabil enhed. En just etableret betydning modsvares i de fleste tilfælde af en modsat betydning, som fortælleren med lige så stor selvfølgelighed meddeler sin læser. Andre gange pointerer han afstanden mellem tegn og betydning ved at gøre diskrepansen mellem analogiens poler så graverende, at betydningen fremstår som åbenlyst uegentlig. Den konstante samtidighed af to uforenelige versioner af virkeligheden situerer Ishmaels fortælling i skæringspunktet mellem egentlig og uegentlig tale. Ved konsekvent at underminere muligheden for at læse verden under en samlende meningshorisont får strategien en afslørende funktion i forhold til den centrale, vertikale orden. Det kan hævdes, at den konsekvente underminering af enhver stabil diskurs truer med at sætte Ishmaels frihed i samme kategori som den romantiske ironikers negative frihed. I dette perspektiv fremstår Ishmaels frihed ulykkeligt bundet til de forestillinger, han kaotisk bryder ned uden mulighed for at gribe »det nye« - for nu at udtrykke det kierkegaardsk. Bagsiden af fortællerens aleatoriske afsløring er den spleen og kedsomhed, der i udgangspunktet får Ishmael til at stå til søs. Men en sådan læsning modsvares radikalt af Ishmaels affirmative holdning til den kropslighed, som står tilbage efter de persiflerende afklædninger.

Ishmaels analogier giver fortællingen sin digressive og tilfældigt 'amorfe' organisering og skaber et horisontalt overfladeunivers. I stedet for en totaliserende re-præsentation af en på forhånd givet mening, som ville lukke narrationen, sættes en betragtningsmåde, hvis organisatoriske princip er helt og holdent æstetisk. For Ishmael findes der ingen anden målestok for den sanselige verdens genstande end den æstetiske anskuelse. I fortællingen konfigureres begivenheder og ting, som de optræder for sansningen, hvilket vil sige i mere eller mindre tilfældig rækkefølge. Tingene springer op og beskrives, hvorefter de forlades igen. Det gælder også for flere af fortællingens personer, som kun optræder en enkelt gang i hele romanen. Manglen på kontinuitet mellem romanens sekvenser betyder ikke, at de beskrevne genstande mister værdi. Tværtimod understreger fortællingens episodiske struktur tingenes øjeblikkelige tilstedeværelse, og dette

22. Melvilles analogiske princip ligger tæt op ad den tyske figur 'Witz' og den engelske 'fancy', som Coleridge modstiller den assimilerende 'imagination'. 'Fancy' og 'Witz' stifter analogiske korrespondenser mellem fænomener direkte hentet fra sansningen. Se M.H. Abrams: The Mirror and the Lamp, New York 1953, p. 175. Jean Paul har givet en definition af 'Witz', som er relevant for Moby-Dick: Vitsen har dog gnistens værdi, hvis ikke lysets; den forskønner dog et minut, hvis den ikke oplyser og varmer noget liv, og den behøver ikke som billeder og systemer først at hente indholdet fra sandheden eller fra sammenhæng og naboskab. [V]ed vitsens fyrværkeri kan jeg intet smede, intet stege, intet hærde endsige smelte«, Jean Paul: Vorschule der Ästhetik, München 1974, p. 472. 
forstærkes yderligere af Ishmaels interesse for dem. Derfor kan Ishmael også afvise enhver billedlig repræsentation af hvalen med henvisning til, at den levende hvals fascinationskraft kun kan erfares ved selvsyn.

Ishmaels uvilje mod at organisere realiteten, hænger sammen med hans manglende tro på et enhedsligt subjekt. I modsætning til Ahab ved Ishmael, at hans jeg ikke er identisk med sig selv. Uden fundering i en transcendental grund er hans jeg faderløst. Forskudt og udstødt fra den patriarkalske ordens metafysiske fundering er jeget principielt altid ude af sig selv. Men hans forståelse af identiteten som en fundamental ikke-identitet redder ham i sidste ende fra undergang. Det markeres i epilogens afsluttende billede af den overlevende Ishmael. Flydende på randen af malstrømmens koncentriske ringe, der objektiverer det metafysiske paradigmes selvdestruktion, samles han endelig op:

»Den næste dag kom et sejl i sigte, nærmede sig og fiskede mig endelig op. Det var Rachel, der under det stadige krydstogt efter sine savnede børn kun fandt endnu en forældreløs« (MD, p. 565/470).

\section{Kroppen}

Ishmael gør sig fri af den selvidentiske subjektforestilling i en kærlig forening med kannibalen Queequeg. Uden at kende hinanden har det umage par fået anvist en seng til deling på kroen »The Spouter Inn« i New Bedford. Ishmael er først oprørt over at skulle sove med en fremmed mand, men deres natlige nærhed udvikler sig efterhånden og kulminerer i kapitlet "Natlig hygge«, der falder umiddelbart efter fader Mapples gudstjeneste. Siddende tæt sammen i sengen oplever mændene et ophør af deres individuelle kropsgrænser, der fører til en erfaring af fuldstændig enhed:

"Vi havde siddet en stund i denne sammenkrøbne stilling, da jeg pludselig [all at once] syntes, at nu ville jeg åbne øjnene; for når jeg er i seng, det være sig ved nat eller dag, sovende elle vågen, har jeg den vane, at jeg altid holder øjnene lukket for desto bedre at kunne koncentrere mig om velbehaget [the snugness of being in bed]. Ingen kan nemlig føle sin egen identitet rigtigt, medmindre hans øjne er lukket - som om mørket i virkeligheden var vort væsensindholds rette element, ihvorvel lyset måtte være mere tiltalende for vort jordiske hylster [our clayey part]. Da jeg åbnede øjnene og kom fra mit eget velbehagelige og selvskabte [self-created] mørke ud i den påtvungne og grove skummelhed fra den uoplyste 
midnatstime [unilluminated twelve-o'clock-at-night], følte jeg et inderligt ubehag« $(M D$, p. 78/55).

Beskrivelsen spiller på romantikkens kodificering af kærligheden. Hegel betegner i sin Ästhetik den romantiske kærlighed som en helhedserfaring, hvor jeget overskrider sig selv i sammensmeltning med den elskede. Det vil sige en ophævelse af jeget i en højere sjælelig enhed, der omfatter verdensaltet. Når jeget med hele sin subjektivitet, gennemtrænger en andens bevidsthed, rækker det ud over sig selv i en inderlighed, som ikke er denne eller hine singulære inderlighed, men den totale inderlighed.

„Så lever denne anden kun i mig, på samme måde som jeg kun er til stede i den; begge er i denne opfyldte enhed først for sig selv og lægger deres hele sjæl og verden ind i denne identitet. [...] Nærmere betragtet beror kærligheden ikke på refleksionerne og forstandens kasuistik, men finder sin oprindelse i følelsen. $\ll^{23}$

Queequegs og Ishmaels intimitet i sengen medfører dog ikke følelsernes ophævelse i en åndelig forening mellem sjæl og verden. Deres forening fastholdes i det kropslige udgangspunkt, som er den udefinerbare, sanselige fornemmelse af »snugness». Det legemlige velbehag danner afsæt for en reformulering af identiteten. Jeg-overskridelsen i den sprogløse følelse formidler identiteten i uophævelig henvisning på den anden i et forhold af gensidig anerkendelse. Den stilfærdige forening adskiller sig fra de kropslige former for exces, man finder hos Bachtin eller Bataille, idet den hverken er grotesk, voldelig eller pornografisk.

Idet Ishmaels identitet erfares i al foreløbighed undgår den at få karakter af en absolut sættelse, som i det kristologiske paradigme. Beskrivelsen vender sig direkte mod en typologisk identitetssættelse, som vi så hos Mapple, for Ishmaels identitet er "selvskabt« og er betinget af, at øjnene er lukket i: »Ingen kan nemlig føle sin egen identitet rigtigt, medmindre hans øjne er lukket - som om mørket i virkeligheden var vort væsensindholds rette element, ihvorvel lyset måtte være mere tiltalende for vort jordiske hylster [our clayey part].«. Forbindelsen mellem lys og »clayey part« refererer direkte til den typologiske identitetssættelses oprindelige formgivning. Men beskrivelsens allusioner til lys og skabelse viser sig som helt og aldeles prosaiske, da Ishmael faktisk åbner øjnene og bliver påtvunget værelsets "grove skummel-

23. Hegel: Vorlesungen über die Ästethik II, p. 182. 
hed«. Øjeblikkets præsens er nedskrevet til den mekaniske tids arbitrære klokkeslæt - »twelve-o'clock-night «-, og det erfares som et grundlæggende realitetsprincip, der gør en ende på situationens fortryllelse. Ishmael reagerer med lede på erfaringen af virkelighedens prosa, men den kropslige erfaring har peget på en pragmatisk mulighed for en jeg-konception, der ikke rekurrerer på et genealogisk hierarki. I stedet for det selvidentiske jegs metafysiske forankring i en genealogisk urgrund kommer kropsfølelsen således til at danne grundlag for en vished om identiteten. Men når identiteten ikke funderes i et stabilt meningskompleks, som formidles gennem blikket, bliver subjektet overladt til sansningens vekslen. Det truer med at overstrege enhver mulighed for at orientere sig blandt tingene. Tabet af orientering forekommer, når individet bliver isoleret og overladt til sine sansefornemmelser. Som kompensation for sansningens labilitet søger Ishmael sikkerhed i de mellemmenneskelige relationer. Kun via en fortsat integration i det konkrete arbejdsfællesskab finder den kropsligt formidlede udgave af virkeligheden varighed. Mandskabets sociale organisation bliver en sikker ramme for Ishmael.

I kapitlet »Håndtrykkene« fremskrives et ikke-hierarkisk fællesskab. Mandskabet på »The Pequod «sidder på skibets dæk og blødgør klumper af spermacetolie med hænderne. Efterhånden udjævner det monotone arbejde med hvalolien de kropslige grænser mellem mændene, når deres hænder tilfældigt griber hinanden i karret:

„Klem til! Klem! Klem! [squeeze!] Hele formiddagen klemte [squeezed] jeg denne spermacet [sperm], til jeg næsten selv smeltede mig inde i den. Jeg klemte [squeezed] denne spermacet, til en sælsom art afsind kom over mig og jeg opdagede, at jeg uden at vide af det sad og trykkede [squeezing] mine arbejdskammeraters hænder deri, idet jeg forvekslede disse med de bløde småkugler. Så overvættes hengiven, venlig og kærlig en følelse avlede denne gerning, at jeg til sidst sad og trykkede [squeezing] deres hænder i eet væk og så dem følelsesfuldt i øjnene, som om jeg ville sige: [...] Kom! lad os trykke hinandens hænder hele vejen, ja, lad os presse [squeeze] os selv ind i hinanden, lad os alle presse hinanden i den ganske verden [squeeze ourselves universally] ind i godhedens egentlige mælk og spermacet. [J]eg har nu opdaget, at mennesket i alle tilfælde til sidst må sænke eller i det mindste forandre sine forestillinger om, hvilken lykke der er opnåelig. I ånden eller fantasien opnår det den ikke, men i hustruen, i hjertet, i sengen, ved bordet, i sadlen, ved arnen eller i naturen [the country]. $\mathrm{Nu}$, da jeg har opdaget alt dette, er jeg rede til at 
klemme [squeeze] spermacet mit ganske liv [eternally] ( $M D$, p. 421/ $348 f)$.

Beskrivelsen konnoterer arbejdet i en seksuel metaforik, som hæver det ud af sin formålsbestemthed og gør det til mål i sig selv. Sprogligt er sekvensen udpræget parallelistisk opbygget. I gentagelsen af ordet "squeeze« opstår en pumpende sproglig rytme, der mimer håndens arbejde. Rytmen formidler relationen mellem krop og sjæl og knytter den isolerede situation sammen med verden. Spermacetklumpernes metaforiske bindemiddel gør stykkets rytmiske udvidelse til en universaliserende auto- eller homoerotisk selvavling. Som i Queequegs og Ishmaels kærlighedsscene fører sammensmeltningen mellem legeme og sjæl ikke til en ophævelse i en højere syntese, men til enhed i den blotte materialitet - »sperm«. Det gør arbejdshandlingen selvreferentiel. På samme måde som beskrivelsen vokser ud af sin egen kværnende rytme, skaber mændenes konkrete arbejde og den metaforiske avling intet nyt produkt. Den homoseksuelle 'produktløshed' strider mod ethvert mytisk funderet paradigme, fordi den underløber forestillingen om en oprindelig grund i genealogien. ${ }^{24} \mathrm{I}$ det maskuline fællesskab på dækket åbner sig således en pragmatisk mulighed, der rammer den patriarkalske samfundsstruktur i sin grundvold. Uden selv at sætte en ny magtstruktur dekonstruerer beskrivelsen hierarkiets fundering af den økonomiske udbytning i en stabil genealogi. Jeg forstår således Ishmaels parodiske besyngelse af en borgerlig livssfære i citatets afsluttende opremsning som en utopisk gestus til virkeliggørelsen af en socialitet uden om typologiens hierarkiske patriarkat og dertilhørende kone, hjerte, seng etc.

\section{Ahab}

Ahabs ydre er typificeret. Hans krop fremstår som en uforanderlig støbning, der vækker mindelser om en klassisk torso, hvis ikke det var for et skæmmende arvæv, der deler ham fra top til tå (MD, p.143/109f). Mødet med hvalen har i dobbelt forstand spaltet Ahab, idet det også har åbnet en uoverstigelig afgrund mellem fremtrædelse og væren. Denne moderne tabserfaring giver ham anledning til at fraskrive genstandsverdenen værdi overhovedet. Ahabs reaktion på den voksende orienteringsløshed står i kontrast til Ishmaels. Under Ahabs centrale optik, "master-eye«, holdes det

24. For en læsning af kapitlet se Ruth Mayer: Selbsterkenntnis - Körperfühlen: Medizin, Philosophie und die amerikanische Renaissance, München 1997, pp. 52-54. 
skabtes omskiftelige væren op mod hans indre følelse af intethed. Det betyder, at forestillingen om verden i sin abstrakte tomhed vokser. Ahab ser ikke de enkelte ting, men udelukkende et angstvækkende billede af en forrykket, tom verden i sin totalitet. Stillet over for tingenes nøgne mangel på mening bliver verden fundamentalt ulæselig eller rettere intet bliver læseligt. Ahab restituerer verdens læsbarhed ved uendeligt at potensere sit eget subjekt. Hvad den sanselige virkelighed taber i betydning, vinder Ahabs monomane jeg i omfang. For havet giver Ahab en frihed til at være, hvad intet subjekt længere formår - en verden i sig selv. Ahab tror han er selvidentisk, mens resten af virkeligheden er faldet fra hinanden i en frastødende ikke-identitet: "Ahab vil altid forblive Ahab [...]«(MD, p. 552/459). Ved at opkaste sit individuelle jeg til herre over virkelighedens negativitet er det muligt for Ahab, at retablere enheden mellem tegn og betydning. Med en vished, der kun er funderet i hans eget absolutte jeg, ved Ahab, at der bag tingenes tilsyneladende tomhed gemmer sig en virkelig og enhedslig væren, som det er muligt at tilegne sig i en voldelig akt.

Men bag sin imperiale facade er Ahab egentlig bare en gammel amputeret sømand, der som kaptajn på »The Pequod« skal tjene fastlandets økonomiske interesser. Ahab kompenserer for sin kropslige afmagt med en sublim retorik. Hans totale og absolutte subjektivitet fordrer en lige så total og absolut af-individualisering af mandskabet. De mange referencer i Moby-Dick til Ahabs magnetiske udstråling skal således forstås i direkte sammenhæng med hans sublime retorik. Et godt eksempel finder man i kapitlet "Agterdækket«, hvor han indvier mandskabet i sin plan om at jage den hvide hval. Her radikaliserer Ahab fader Mapples fremmedgørende blik til et veritabelt elektrochock, der gør mandskabet til hans:

"Det var, som om han ved en ukendt indre viljesakt gerne ville have rystet dem op [shocked into them] til den samme flammende lidenskab som den, der var akkumuleret i hans eget magnetiske livs leydnerflaske. De tre styrmænd stod kuet foran hans stærke, lidenskabelige og mystiske fremtoning«( $M D$, p. 183/145f).

Fra og med dette stød opstår en kras diskrepans mellem den differentierede gruppe af individuelle stemmer, som Ishmael præsenterer ved rejsens begyndelse, og den disciplinerede hob i de sidste kapitlers ekstremt centraliserede plot:

"[S]åledes smededes også alle besætningens individualiteter: denne mands mod, hin mands frygt, den enes synd og den andens skyld, sam- 
men til en enhed [oneness] og rettedes alle mod hint skæbnesvangre mål, som deres eneste herre og køl: Ahab, pegede imod«(MD, p. 546/455).

Ligesom Mapples retoriske manipulation er Ahabs retorik en maske, der dækker over hans egentlige mål, nemlig kontrol:

»Det vil ej heller kunne undgås, at man efterhånden i nærværende beretning ser, at han undertiden skjulte sig [masked himself] bag disse former og skikke og i den enkelte situation gjorde brug af dem til andre og mere private formål, end de oprindeligt var bestemt til at tjene« $(M D$, p. 163/ 129).

I »Agterdækket« udsætter Ahab en guldmønt som dusør til den, der først ser hvalen. Mønten bevæger sig siden ledemotivisk gennem romanen som det cirkelrunde emblem på Ahabs centralistiske verdensbillede. Men skibets sobre førstestyrmand, Starbuck, nægter først at tage del i det gale projekt. Starbuck fanger hvaler for at tjene penge, og at hævne sig på et dyr er for ham ikke blot vanvid, men også blasfemisk. Ahab svarer:

"Alle synlige genstande er kun som papmasker. Men i enhver begivenhed - i den levende handling, den ubetvivlede dåd - er der et eller andet ukendt, men dog tænkende, der gemmer omridsene af sine træk bag den tomme maske. Hvis en mand vil slå til, må han slå gennem masken! Hvordan kan fangen nå ud uden at bryde gennem muren? For mig er den hvide hval hin mur, som er skubbet tæt hen mod mig. Stundom tror jeg, at der intet er på den anden side. Men alligevel ved jeg det« $(M D$, p. 181/ 144).

Donald Pease har læst Ahabs berømte svar som en tour de force i retorisk overbevisning. ${ }^{25}$ Bag en sublim maskering udmanøvrerer Ahab sin styrmand. Ifølge Pease tager Ahab retorisk kontrol over situationen ved at retfærdiggøre sit forehavende i en dybere og mere omfattende anfægtelse end Starbuck. Hvis Starbuck kun dræber hvaler for den økonomiske gevinst på Nantuckets marked, er han ikke i stand til at se dem som repræsentanter for et formål dybere end profit. Ved at indskrive hvalen i et kosmisk drama gør Ahab dermed Starbucks argument potentielt blasfemisk. Når Starbuck

25. Donald Pease: "Moby-Dick and the Cold War Paradigm«, in Walter Benn Michaels and Donald Pease (eds.): The American Renaissance Reconsidered, Baltimore and London 1985, p. 142. 
behandler hvalen som "papmaske« for sine økonomiske interesser, bekræfter han Ahabs moralske dom. Maskeret taler Ahab som en mand, der ikke længere stiller sig tilfreds med en religion, der er baseret på økonomiske hensyn. I stedet for at svare på Starbucks anklage, fordømmer han Starbucks argumentation og vender den samtidig til en yderligere retfærdiggørelse af sit eget forehavende. I situationen synes Ahab at vinde debatten, fordi han i modsætning til Starbuck ikke er bundet af en religiøs diskurs, men kun beror på sit eget mægtige jeg. Spørgsmålet er dog om Ahabs imperiale autonomi, som Pease læser som grundlæggende sekulær i forhold til Starbucks religion, ikke selv er en maske for en langt mere arkaisk personlighedsmodel. ${ }^{26}$

»Der var da kun ringe grund til at betvivle, at Ahab lige siden dette næsten dræbende møde havde næret en vild hævnfølelse mod hvalen, en følelse, der blev desto mere flammende, efterhånden som han helt sygeligt kom til at identificere den med ikke alene alle sine legemlige plager, men også med alle sine sjælelige bekymringer. Den hvide hval svømmede for hans blik som det monomaniske indbegreb [incarnation] af alle de skadelige stoffer [malecious agencies], som nogle dybttænkende mennesker føler ætse i deres indre, til de til sidst kun lever med en halv lunge og et halvt hjerte, af al den uhåndgribelige ondskab, der har eksisteret siden tidernes morgen, der selv efter nutidens kristnes opfattelse hersker over den halve verden, og som Orientens gamle ophiter ærede i deres djævlestatue. Men Ahab faldt ikke på knæ og tilbad ikke det onde sådan som disse; i sit afsindige had overførte han dets begreb til den forhadte hvide hval og rejste sig trods sin lemlæstelse til uforsonlig kamp mod det. Alt hvad der mest gør afsindig og volder pine, alt hvad der roder bærmen til vejrs i livet, al sandhed med ondskab i sig, alt hvad der slapper senerne og døver hjernen, al snedig djævelskab i liv og tanke - alt ondt personificeredes for den afsindige Ahab synligt og blev praktisk angribeligt [practically assailable] i Moby-Dick. På hvalens hvide pukkel dyngede han summen af al vrede og had, som hans race har følt fra Adams dage $[\ldots] \ll(M D$, p. 198f/160) .

Hvalen inkorporerer en oprindelig negativitet, som kun en yderligere negation kan fordrive. Dens personificerede fylde billedliggør verdens forrykkethed fra oprindelse til apokalypse. Med Ahabs personificering af dyret indsætter han det værendes ulidelige vekslen i en stabil genealogi. Ved at

26. Ibid. 
tingsliggøre intetheden reducerer han verdens heterogene mangfoldighed til enhed. Ikke blot for at forstå den sanselige verdens tvetydige kaos, men også for at gøre det værendes mysterium bogstaveligt 'fatteligt' og "praktisk angribeligt«. Fikseringen af ondskaben i et fastsat billede gør det muligt for Ahab at ramme den med sit eneste våben, den sublime retorik - „slå gennem masken«. Ahabs repræsentation af hvalen i billedet af sit eget indre har karakter af en navngivning, som fatter det værendes totalitet i et koncentreret verdens-billede. Som Adam selv benævner Ahab hvalen. Navngivningen er første skridt i enhver domesticering af realiteten. Ahabs amerikanske Adam gentager den præfigurerede Adam, og afslører den faktiske kontinuitet mellem det puritanske paradigme og det selvberoende autonome subjekt, der i Ahabs skikkelse optræder under dække af en sekulær logik. Ligesom det typologiske paradigme skulle depotensere angstvækkende tvetydigheder i den ny verdens vildnis, gør Ahabs antropomorficerende udgave af det autonome jeg det muligt at inkarnere og repræsentere de frastødende tilfældigheder i et enkelt og afsluttet billede af Moby Dick. Men heri ligger også hans undergang. Eftersom Ahabs radikale humanisering af virkeligheden imaginært leverer sin egen virkelighed, ophæves grænsen mellem jeg og verden. Tingenes rædselsvækkende spaltning mellem ydre masker og indre tomhed opleves som en splittelse af Ahabs eget indre, der deles i en projektiv bevidsthed og en åndelig tomhed.

Det bliver tydeligt i kapitlet "Søkortet«, der indeholder en af romanens mest fortolkede situationer. Ahab sidder i sin kahyt, og med tankens kraft alene kortlægger han ruten til det endelige møde med sin ærkerival. Gennem kartografens intense koncentration blander de bekymrede rynker i kaptajnens ansigt sig med pennens snørklede linjer på kortet. Samtidig bliver hvalens vandringer på havet beskrevet i analogi med kroppens arterier. Men kraftanstrengelsen har mærket den mægtige plotter på »The Peqoud«. Da Ahab kommer op fra sin kahyt lyser vanviddet ud af ham:

„Dette var næppe ukontrollable symptomer på nogen skjult svaghed eller angst for hans egen beslutning, men snarere de tydeligste beviser på dennes styrke. Thi ved sådanne lejligheder var det ikke den afsindige Ahab, den beregnende, ubøjeligt beslutsomme forfølger af den hvide hval, ikke den Ahab som var gået til ro i sin køje, der fik ham til at styrte fra den i rædsel. Drivkraften hertil var det evige, levende princip eller sjælen [soul] i ham. Og da den i søvne for en tid var skilt fra den kontrollerende hjerne [characterizing mind], der til andre tider benyttede den som ydre redskab eller drivkraft [agent], søgte den spontant at undvige fra det svidende naboskab [contiguity] til dette desperate organ, som den 
i øjeblikket ikke længere var en integrerende del af. Men da hjernen ikke eksisterer undtagen i forbindelse med sjælen, må der i Ahabs tilfælde være sket dette, at hans altbeherskende forsæt herskede over alle tanker og forestillinger med en sådan indædt viljeskraft, at det stik imod guder og djævle tvang sig til at antage skikkelse af et slags selvskabt, uafhængigt væsen, ja, at det kunne leve og brænde hedt, mens den almindelige livskraft, som det var bundet til, flygtede skrækslagen fra dette uønskede og faderløse nyfødte væsen. Derfor var den forpinte ånd [tormented spirit], der stirrede ud af det legemlige øjne, når det, der syntes at være Ahab, styrtede ud fra sit rum, for nærværende kun et tomt hylster, et uformeligt søvngængeragtigt væsen, ganske vist nok en stråle levende lys, men uden nogen genstand at farve og derfor i sig selv tomt og farveløst« $(M D$, p. $217 / 174 f)$.

Ahabs forbrændte krop og glødende øjne vidner - udefra såvel som indefra om fremmedbestemtheden af hans strategi. Han har ikke selv kontrol over den sublime enhedsstiftende magt, han anvender. Skønt Ahab ser sig mægtig til at genskabe meningen med verden i en original sublim sættelse, forbliver hans bestræbelse en ulykkelig gentagelse. Hans intense forsøg på imaginært at fylde verdens tomhed $\mathrm{i}$ en identifikatorisk akt, intensiverer samtidig den indre afstand mellem hans »kontrollerende hjerne«, "sjæl» og »forpinte ånd «. Hermed fragmenteres hans allerede amputerede jeg yderligere. Forsøget på at gentage den oprindelige akt splitter hele tiden, hvad det skulle sone og forskyder totaliteten. Ahab er selv et redskab for et paradigme, han ikke har erkendt. Den imperiale prægning, der garanterer hans selvberoenhed, peger samtidig på en grundlæggende afmægtig uoriginalitet.

\section{Tiden}

Ahabs personificering af verdens oprindelige forrykkethed i den hvide hval modsvares af Ishmaels behandling af hvalen i kapitlet "Hvalens hvidhed". Ishmael vender så at sige Ahabs retoriske strategi på hovedet. I stedet for at personificere hvalen som totalitet, opremser han de uendelige betydninger af farven hvid. Hvid er en samlet betegnelse for alt muligt - fra det mest ophøjede til det mere profane. Ved at nævne farvens betydninger i tilfældig rækkefølge afpersonificerer han hvalen, indtil den fremstår som det ingenting, den faktisk er: 
"[A]ltsammen [er] kun snedige bedrag, der ikke reelt er de pågældende substanser iboende, men kun pålægges dem udefra, så at den ganske guddommelige natur i virkeligheden kun maler som skøgen, hvis lokkemidler intet andet dækker end lighuset indeni [...] (MD, p. 211/170).

Ishmaels tilgang til hvalens hvidhed, som fylder den abstrakte tomhed med enhver mulig betydning uden at samle betydningen i et afrundet hele, karakteriserer som før nævnt hans æstetiske strategi som fortæller.

Hvad angår fortællingens tid, skriver Ishmael fra 'midten'. Han har ikke som Ahab overblik til at organisere fortællingen teleologisk i forhold til en prækonciperet slutning, der retrospektivt ville bringe overensstemmelse mellem begyndelse, midte og slutning. Den form for organisering af tiden, som herved opstår, har Frank Kermode betegnet som chronos. Chronos er den tid, som ikke er humaniseret i en menneskelig bevidsthed og dermed ikke konfigureret i et plot: "[H]vilket simpelthen er 'one damn thing after another' ${ }^{27}{ }^{27}$ Ishmaels verden står i direkte modsætning til Ahabs, der i eminent grad underlægger tiden sin egen bevidsthed. Ahab organiserer alting i forhold til det afgørende øjeblik, hvor han skal møde sin ærkefjende, den hvide hval. Ahab opfatter hermed tiden som kairos. Kairos betegner i teologien det meningssvangre øjeblik i historien, forstået som en stadig forløsningshistorie mod gudsrigets komme og tidens fylde, pleroma. Frank Kermode giver følgende definition på kairos: „Forestillingen om opfyldelse er essentiel: kairos forvandler fortiden, validerer typer og profetier fra Det gamle Testamente, skaber overensstemmelse med oprindelser såvel som endemål. $«^{28}$

Ser man Moby-Dick i forhold til en aristotelisk plotmodel, hvor karakterbeskrivelsen er underlagt plottet, er forskellen mellem Ahab og Ishmael tydelig. Ahabs karakter fremstår med så stor grad af bestemthed, at han for læseren synes overdetermineret. ${ }^{29}$ Hans arkaiske tale, sublime gestik og fremtræden i øvrigt er alle underordnet hans monomane projekt. Omvendt er Ishmael mestendels præsent i romanen som en figurløs stemme, der forbinder de enkelte sekvenser. Vi ved ikke, hvordan han ser ud, hvor han kommer fra, og end ikke hans navn vidner om en stabil identitet, idet han i

27. Frank Kermode: The Sense of an Ending, New York 1966, p. 47.

28. Ibid.

29. I sin anmeldelse af Moby-Dick i Literary World d. 22. 111851 beklager Evert A. Duycking, sig over den udførlige karaktertegning af Ahab: „Den intense kaptajn Ahab er trukket for langt ud; noget mere af ham kunne, synes vi, være overladt til læserens fantasi ", Brian Higgins \& Hershel Parker (ed.): Herman Melville - The contemporary Reviews, New York 1995, p. 384. 
romanåbningens berømte læserhenvendelse fraskriver sig egennavnets mulighed for identifikation: »Kald mig Ishmael« $(M D$, p. 25/12). Uden et personligt plot til at stifte hans person som karakter trænges Ishmaels figur i baggrunden og narrationen antager karakter af en encyklopædisk essayisme.

Distinktionen mellem de to tidsopfattelser fordeler forholdet mellem narrativ progression og udsættelse på selv samme roller. De mange kapitler om livet på havet, som Ishmael udmaler med stor omhu, nedsætter fortællingens tempo, og lader faktisk den hvide hval leve ved hele tiden at udsætte dens voldelige død. Ishmaels udsættelser viger først, da »The Pequod « nærmer sig sit mål og Ahab for alvor tager over. I romanens sidste tre kapitler »Jagten« forsvinder Ishmael helt fra synsfeltet og fortællingens fart øges voldsomt. Fra den nærmest tidløse omflakken på havet koncentreres den skæbnesvangre finale i tre dages intens jagt.

Jeg anser forskellen mellem de to tidsbegreber, kairos og chronos, som grundliggende for forskellen mellem Ahabs centralistiske verdensbillede, der søger at overkomme oplevelsen af tidslig diskordans mellem fortid, nutid og fremtid i et radikalt meningsstiftende øjeblik og Ishmaels horisontale ophobning af detaljer og vidensbrokker. Med udgangspunkt i fortællingens tidslige dialektik kan man måske forklare samtidens reaktion på Melvilles roman, der blev opfattet som en både vanvittig og ond bog. ${ }^{30}$ For udspaltningen af romanens narrative energi i de to kategorier er netop radikal i forhold til en 'normal' bevidsthed. Mens en normal person justerer sin subjektive tidsfornemmelse i forhold til den omgivende virkelighed, er både Ahab og Ishmael ekstreme. Ahabs imperiale storhedsvanvid består netop i, at han humaniserer tiden så radikalt, at hans virkelighedsversion fremstår som 'verrückt', mens der på den anden side er noget grundlæggende inhumant ved, at Ishmael næsten helt undlader at organisere tiden i henhold til sit eget livsforløb.

Moby-Dicks iøjnefaldende formløshed tager prosaen på sig. Romanens excentriske struktur og tentative gennemspilninger af en encyklopædisk videnshorisont holder fortællingen åben. Hermed undgår Herman Melville at tage del i den tvang, der synes at være det eneste middel for den, der ikke vil indse, at verden er blevet prosaisk. Fader Mapple og Ahabs forsøg på at lukke afgrunden mellem nutid og fortid, tegn og betydning i billedet af en ubesmittet oprindelse, viser sig som et fatalt forehavende, som blot forskyder nærværet af den sandhed, det vil gribe. Når billedet af en indre sammen-

30. Jvf. bl.a. anmeldelsen i Athenæum d. 25.10. 1851, op.cit. p. 356 
hæng én gang for alle er revnet og har forvandlet tingene til et maskepi, kan kun loven og kontrollen skjule bruddet. Men ved at tilsløre fraværet af den sandhed, den skulle åbenbare forvandles loven uvægerligt selv til en maske. Typologien er et gennemgående eksempel på denne ulykkelige dialektik i Moby-Dick. Typens sublime præg af skaberens oprindelige akt er i romanen degenereret til de nøgne spor af en desperat gestus efter meningen. Med sin retorik gentager Ahab fatalt et arkaisk paradigme, der ikke har gyldighed. Hans sublime ord inkarnerer ikke længere den sandhed, de hævder, og tilbage er kun formens voldelige gevandter.

Som karakter bliver den faderløse Ishmael opløst i sin fortællings essayisme, men der er et væsentligt identifikationspunkt, som består - kroppen. I Moby-Dick er kroppen den sidste invariabel efter, at tingene har mistet deres indre sammenhæng. Den er hele tiden til stede i Ishmaels fortælling, og fremstår i dobbelt forstand som det, der ligger bag de analogiske afklædninger i romanen. Dobbelt, fordi det på den ene side er den legemlige væren, som splitter perspektivet i romanen, mens det på den anden side også er kroppen, der står tilbage, når de imaginære konstruktioner har vist sig at være bedrag. 